\title{
UNIVERSALIZATION OF PRIMARY EDUCATION - A ROADMAP TO IMPROVE ENROLMENT IN PRIMARY EDUCATION DURING COVID-19
}

\author{
Dr. S. Sudha
}

\begin{abstract}
Education is any country helps to make a more civilized society. Implementation of education in making a better in making a better society is possible through the universalization of elementary education. The elementary education is the creation of progressive system which helps in providing education to all. The universal elementary education has its base from Millennium Development goals before 2000. In India the primary education is done through funding and District Primary Education Programme. This programme has been quite successful and helps to link districts and state level educational plans. This paper helps to provide suggestions like having volunteers who are expert in digital and suggesting changes in curriculum etc. Still India is facing lot of challenges and lot of efforts need to be taken so that needy and poor will be able to access the universal elementary education.
\end{abstract}

Keywords: universal elementary education, education, millennium development goals, sustainable goals

\section{INTRODUCTION}

Education is any country helps to make a more civilized society. Implementation of education in making a better in making a better society is possible through the universalization of elementary education. The elementary education is the creation of progressive system which helps in providing education to all.

Education for all, is vital to a country like India. This is made possible by compulsory schooling. This law was adopted by the government between 1918 and 1930s. For implementation of the policy requires adequate and additional resources.

The resources help to bring changes in the educational system and in turn helps to improve the gross enrolment into primary education. This indeed helps to retain children in schools and reduces the school dropout rates. The concept of elementary education helps to improve the literacy rates in respective states of India. Universal education was the base to improve primary education in India. Elementary education was targeted among the age group of 6 to 14 years. The National Education Policy of 1986 is responsible for the implementation of primary education.

\section{UNDERSTANDING UNIVERSAL ELEMENTARY EDUCATION}

The universal elementary education has its base from Millennium Development goals before 2000. But now as per UNESCO report of 2016 states education as sustainable goals. The report further states that the universal primary education will be achieved by 2049 . 
The universal elementary education can be categorised in to two types:

\begin{tabular}{|c|c|}
\hline Stage & Age group \\
\hline Primary stage & $6-14$ years \\
\hline Upper primary stage & $11-14$ years \\
\hline
\end{tabular}

As per the New Education Policy 2020 the mandatory or elementary or universal or primary education for the target age group has been changed to 3years to 18 years from 6 years to 14 years. The UNESCO report of 2020 further likes to include factors like ability and motivation as to education. Further due to the COVID - 19 situation tools like online monitoring tools and storytelling as the latest and interesting way for attracting children as to elementary education (UNESCO, 2020).

The major features as to Universal elementary education are: 1. Improving and increasing school enrolment especially girl children 2. Giving accessibility to schools 3 . Providing good quality education 4. Proper financial resource allocation to education 4. Increase children retention in schools etc. All the recommendations were provided by the Sargent Committee.

\section{MILLENIUM DEVELOPMENT GOALS AND EDUCATION}

To make education accessible to all children around the world is said to be the main of millennium development goals (Stacy A. Rosie, 2012). This universal education can be implemented by all countries at various levels. In India the primary education is done through funding and District Primary Education Programme. This programme has been quite successful and helps to link districts and state level educational plans.

The sustainable goals as to education highlights that by the year 2030, children ie both boys and girls will complete quality, equitable and free primary and secondary education (Linzi J. Kemp. 2013).

\begin{tabular}{|l|l|}
\hline \multicolumn{1}{|c|}{ United Nations MDG } & \multicolumn{1}{c|}{ MDG in India } \\
\hline The United Nations Millennium & India has progressed and expanded new schemes as to \\
$\begin{array}{l}\text { Declaration, to fight poverty, } \\
\text { illiteracy, discrimination against } \\
\text { women }\end{array}$ & $\begin{array}{l}\text { rural health } \\
\text { (2005), empower women, improve maternal health, fight } \\
\text { diseases like HIV and development of global partnership } \\
\text { for achievement of goals }\end{array}$ \\
\hline
\end{tabular}

Source: google.com

\section{STATUS OF UNIVERSAL ELEMENTARY EDUCATION IN INDIA DURING COVID-19}

The Universal elementary education in India needs far more to be achieved. The MDG and sustainable goals have been trying to improve the field of education.

It is known that there are lot of challenges existing in the universal elementary education in India. Specific challenge is the enrolment of children in to elementary education.

They are: 1. Needs lot of investment in Infrastructure improvement

2. During the time of COVID-19 online classes has become inevitable (Raja, Kallarakal,2020). Internet facilities need to be upgraded and made accessible to all children especially in rural areas.

3. More online tools and other pedagogy can be followed to improvise education. 
4. The government and private school teachers can be trained in digital skills and intelligence

5. Have volunteers who are expert in digital.

6. Curriculum can be reshaped for all classes (Brookings 2020).

7. Bringing in more accountability (James H. Bisbee et.al,2019).

\section{FUTURE WAYS TO IMPROVE ENROLMENT IN SCHOOLS TO IMPROVE UNIVERSAL ELEMENTARY EDUCATION}

The following ways can be handled to improvise elementary education and enrolments in schools in India

-Introducing technology-oriented teaching which helps to build the curiosity for students to learn

-Recruiting, training and capacity building of teachers to handle subjects in more creative way. -adoption of storytelling techniques towards teaching

-ensuring safety of girl children in schools and improving the environment (Richard A. Meganck

-providing more hygienic, healthy mid-day meals to children., 2010).

- More investment in technological infrastructure.

-Making more efforts to improvise retention rates and reducing the drop out rates of children.

-taking more efforts to convince parents to send their children to schools.

-improvising more basic amenities like toilets, etc

-more concentration to be given to children with special needs.

-more importance to values, skills, numeracy and problem solving.

-reviewing the broad strategies as to sustainable financing, improving quality and main stream educational administration, increasing transparency and implementing practical plans.

-to introduce more robust policies and programs from government side (Nwachukwu Prince Ololube et.al 2008)

\section{CONCLUSION}

The concept of universal elementary education can be implemented in more planned manner. It is important that more regulations need to be brought so that the poor and needy people can be benefitted and India will be 100 percent literate in the coming years to come. 


\section{References}

1. Linzi J. Kemp (2013), Progress in female education and employment in the United Arab Emirates towards Millennium Development Goal (3): gender equality, Foresight, VOL. 15 NO. 4 2013, pp. 264-277,

2. James H. Bisbee, James R. Hollyer, B. Peter Rosendorff, and James Raymond Vreeland (2019), The Millennium Development Goals and Education: Accountability and Substitution in Global Assessment, International Organization 73, Summer 2019, pp. 547-78.

3. Nwachukwu Prince Ololube, Daniel Elemchukwu Egbezor, Peter James Kpolovie (2008), EDUCATION POLICIES AND TEACHER EDUCATION PROGRAMS: MEETING THE MILLENNIUM DEVELOPMENT GOALS, Journal of Teacher Education for Sustainability, vol. 9, 2008, pp. 21-34.

4. Raja, M. A. S., \& Kallarakal, T. K. (2020). "COVID-19 and students perception about MOOCs" a case of Indian higher educational institutions. Interactive Technology and Smart Education.

5. Richard A. Meganck (2010), The role of water education in achieving the Millennium Development Goals? Rev Environ Sci Biotechnol (2010) 9:79-80.

6. Stacy A. Rosie (2012), Examining Stakeholder Perceptions of Educational Success in the Malagasy Public Education System, University of Phoenix, UMI Number: 3536379, pp.1-237.

\section{Text Book References}

1. Brookings (2020), https://www.brookings.edu/blog/education-plusdevelopment/2020/05/14/covid-19-in-india-education-disrupted-and-lessons-learned.

2. Damodar Mohapatra, Avaya Kumar Nayak(2016), Universalisation of Elementary Education-Policies and Programmes, Neelkamal Publications Pvt.Ltd, Hyderabad, India, ISBN 978-93-85877-26-1, pp.1-194.

3. Dipak Kumar Bhattacharyya (2015) Training and Development, Sage Publications Pvt Ltd, USA, ISBN 978-93-515-0140-4, pp.1-286.

4. Dash B.C, (2017), A Textbook of Educational Technology, Wisdom Press, India, ISBN 978-93-80199-41-2, pp.1-283.

5. Madhulika Sharma (2018), Elementary Education and Literacy, Neelkamal Publications Pvt.Ltd, Hyderabad, India, ISBN 978-93-86725-69-1, pp,1-241.

\section{Webliography References}

1. https://www.mindler.com/blog/national-educationpolicy/\#: :text=Some $\% 20$ of $\% 20$ the $\% 20$ Major $\% 20$ Highlights,of $\% 20$ Anganwadi $\% 2 F$ $\% 20 \mathrm{pre} \% 2$ Dschooling.

2. https://unesdoc.unesco.org/ark:/48223/pf0000245752

3. https://en.unesco.org/gem-report/report/2020/inclusion

\section{By Dr.S.Sudha, Associate Professor \& Research Supervisor, School of Management Studies, Vels Institute of Science, Technology and Advanced Studies, narasimhan.sudha@gmail.com}

